\title{
IMPLEMENTATION OF URBAN BUILDING ENERGY MODELING IN HISTORIC DISTRICTS. SEVILLE AS CASE-STUDY
}

\author{
ROSANA CARO-MARTÍNEZ \& JUAN J. SENDRA \\ Instituto Universitario de Arquitectura y Ciencias de la Construcción. Escuela Técnica Superior de Arquitectura. \\ Universidad de Sevilla, Spain.
}

\begin{abstract}
Buildings represent $40 \%$ of the European Union's final energy consumption and are largely of residential use. From 2006 to 2016, existing European housing stocks have been analysed at national level to make the energy refurbishment processes transparent and effective. However, at the metascale of regions, cities or neighbourhoods, case-by-case analysis using Building Energy Models (BEM) becomes an unfeasible decision-support tool. To try to overcome this limitation, the nascent field of Urban Building Energy Modelling (UBEM) is making substantial progress in the assessment of building energy performance at urban scale. Still, most of the UBEM projects rely upon archetypes - i.e. virtual or sample buildings illustrative of the most frequent characteristics of a particular category, and the definition and description of such archetypes may compromise their reliability. This paper presents an alternative UBEM approach, especially designed for the homogeneous historic districts of cities where a significant proportion of the buildings are under preservation rules. These rules can restrict the scope of the measures to improve their energy efficiency or limit the possibility of implementing renewable energy systems. We introduce a new parameter (HAD) to classify blocks according to their heritage asset density. HAD is then mapped onto the study-area and the sample block is selected as representative of the most frequent HAD category. Using the historic ensemble of Seville as case-study, this paper shows results in energy consumption on a district scale and proposes a set of solutions to improve the energy efficiency of the buildings while respecting the heritage preservation rules. To support consistent policy decisions, validation of these results has been carried out, by in-situ monitoring of a representative number of dwellings.

Keywords: energy demand, historic buildings archetypes, mediterranean climate, residential building stock, thermal rehabilitation, urban building energy modelling, urban heritage protection.
\end{abstract}

\section{INTRODUCTION}

In accordance with Europe 2020 targets about climate change and energy sustainability, DIRECTIVE 2012/27/EU on energy efficiency came into force for all the States in 2013. According to its Article 4 concerning building renovation, Member States may decide not to apply the energy efficiency requirements to 'buildings officially protected as part of a designated environment, or because of their special architectural or historical merit, in so far as compliance with certain minimum energy performance requirements would unacceptably alter their character or appearance'.

The combined application of energy retrofit with renewable energy to protected buildings in historic districts can bring several beneficial effects: first, it can help to attain EU climate targets; second it could make the use and occupation of housing in these districts more attractive, reducing costs and improving comfort for dwellers; and it may also counteract the ongoing commodification of whole historic districts which now recognized as a cause of unsustainable metropolitan imbalances. However, according to the EFFESUS Research Project [1], most European countries, following Article 4, decided to waive the energy efficiency measures when it comes to protected historic buildings or environments. Why? 
Renovation of historic buildings is perceived as a cultural risk, and therefore, local legislations establish restrictions to the transformations potentially applicable, with stricter rules the higher the relevance or uniqueness of the heritage assets of the building or environment. Nonetheless, a major part of protected buildings in Europe are not monuments of outstanding artistic or historic value, but rather buildings catalogued with lower levels of protection. As a consequence, the range of authorized transformations may be significant. As the exception contained in Article 4 aforementioned does not discriminate between monuments of high protection levels and other protected buildings with lower levels, and taking into account that the vast majority of buildings in historic ensembles are of residential use, the political decision to waive energy efficiency requirements to renovations in historic districts, sentences them to comfort obsolescence or to energy wasting, without a thorough consideration of the socio-economic consequences.

In Europe 28, the percentage of dwellings older than 1945 (in total residential stock) has a mean value of $22.69 \%$ [2]. European residential stock is responsible for $25 \%$ of total energy consumption [3]. In Spain 12.84\% of the total number of dwellings are older than 1945 but half of the residential building stock were constructed before 1981 [4], year in which the first regulation concerning energy saving was mandatory. Spanish residential building stock accounts for $17 \%$ of total energy consumption [3]. Incentives encouraging Spanish owners to improve their buildings energy performance (protected or not) are usually implemented at regional or municipal level. They are taken irregularly and based in general assumptions and standard, partly inaccurate and untested, energy efficiency 'formulas'.

The importance of designing new integrated approaches to implement measures for energy balance improvement, cost reduction and reducing carbon footprint while respecting protection requirements in historic districts is quickly rising (see, for example, Refs. [5] and [6]), and some EU research programs have been devoted to this aim [7-9]. Since significant cultural values make retrofitting process in heritage buildings more complex, specific analytical tools and methods should be develop. While BEM (Building analysis of Energy Models) has proven useful in the analysis of single buildings, it becomes impractical at the meta-scale of regions, cities or even neighbourhoods. In recent years, substantial progress has been made to assess building energy performance at urban scale and a nascent field of research called urban building energy models (UBEM) $[10,11]$ is expected to contribute to solve the question. Still, most of the UBEM projects rely upon archetypes, i.e. virtual or sample reference buildings illustrative of the average building in terms of climatic conditions and functionality. As there is no standardized method to determine them, using these archetypes may compromise the reliability of the UBEM methods.

The aim of this work is to present an alternative UBEM method designed for morphologically homogeneous historic districts where a significant proportion of their buildings are under preservation rules. The method proposed, focused on residential use, takes heritage value into account in the parametrization process and quantifies block-scale heritage assets. Using Seville (Spain) as case-study, it delivers dynamic-simulation results on thermal behaviour for the quantification of the potential capacity of historic ensembles to implement existing and new decarbonisation technologies at the district-scale "without harming the heritage values and minimizing/eliminating all risks for the buildings themselves" [12].

\section{METHODOLOGY}

In this alternative UBEM approach, based on archetypes of blocks, heritage values of the buildings were taken into account for urban segmentation. Especial attention was paid to the 
method for choosing the sample-block, as its calculated energy balance would be thereafter, scaled up to the neighbourhood level. From individually simulated sample-buildings (working with multi-zone dynamic thermal modeling) extracted from the sample-block, up-scaling of results to block level was made by apportionment of the results per solar orientation and floor area. The GIS tool ArcMap 10.2.1@ was used in order to describe the spatial distribution of heritage assets in the study-area and to map its frequency distribution. Shapefile data containing heritage listing grades of buildings were kindly provided by the Sevilla City Planning Department.

\subsection{Case-study}

Seville (Andalucía, Spain) was chosen as case-study because of four main reasons: firstly, Seville contains a large historic urban complex designated as 'Conjunto Histórico' since 1990 and catalogued at regional level as 'Bien de Interés Cultural', the highest protection grade existing in Spain. It spans 5.54\% of the municipal area and holds $8.5 \%$ of its total population [12]. Secondly, it contains the Cathedral-'Alcázar'-'Archivo de Indias' ensemble, which is listed in the World Heritage List since 1987. This fact directly affects the potential urban transformations in a 100 metres radius around it, or even farther if its visual integrity were affected. Thirdly, over the last 30 years, the 'Conjunto Histórico' has been under a special plan with binding policies concerning building preservation, refurbishments and demolition, as well as urban infrastructure, resulting in the homogeneity in shapes, materials and proportions that have reached us; and lastly, $62 \%$ of its buildings are protected (6.875 of 11.029).

The local policy on heritage protection classifies the building stock within the 'Conjunto Histórico' in four grades of protection: A and B (for monuments), C for buildings of typological interest and D for buildings, which contribute to maintain urban identity. Listing grades are assigned case-by-case.

\subsection{Study-area}

As this work is focused on historic housing, in order to deduce consistent energy balance results at district level from the calculated outcomes at block level, the morphological homogeneity of the urban district was considered relevant. Consequently, the study-area selected (Fig. 1) comprises the urban land enclosed inside the XII century defending city walls limits. It covers 345.53 hectares. Its current population is 59721 inhabitants, living in 539 blocks and 10559 buildings, of which $67 \%$ are listed (7050 buildings) [13]. Relative to the south sector, the north sector is more densely populated and more homogeneous morphologically, showing a prevalence of housing and traditional commerce. Therefore, the sample block will be selected from the north sector.

In the study-area, grades A and B listed buildings represent $5.7 \%$ of the existing stock and $8.6 \%$ of the listed pool; the rules preserving its heritage assets may restrict considerably the scope of energy retrofits or renewable energy systems implementation. Yet, grades C and D listed buildings represent $60 \%$ of existing stock and $90 \%$ of the listed pool; their possibilities of transformation are much wider, so it is on these buildings where the potential for improvement of the historic city resides.

Every block in the study-area holds a specific mixture of buildings listed or not, in variable number and protection grade. A typical block is a compact assembly of a variable number of three or four-floor buildings with flat roofs. Each building usually occupies an oblong plot 


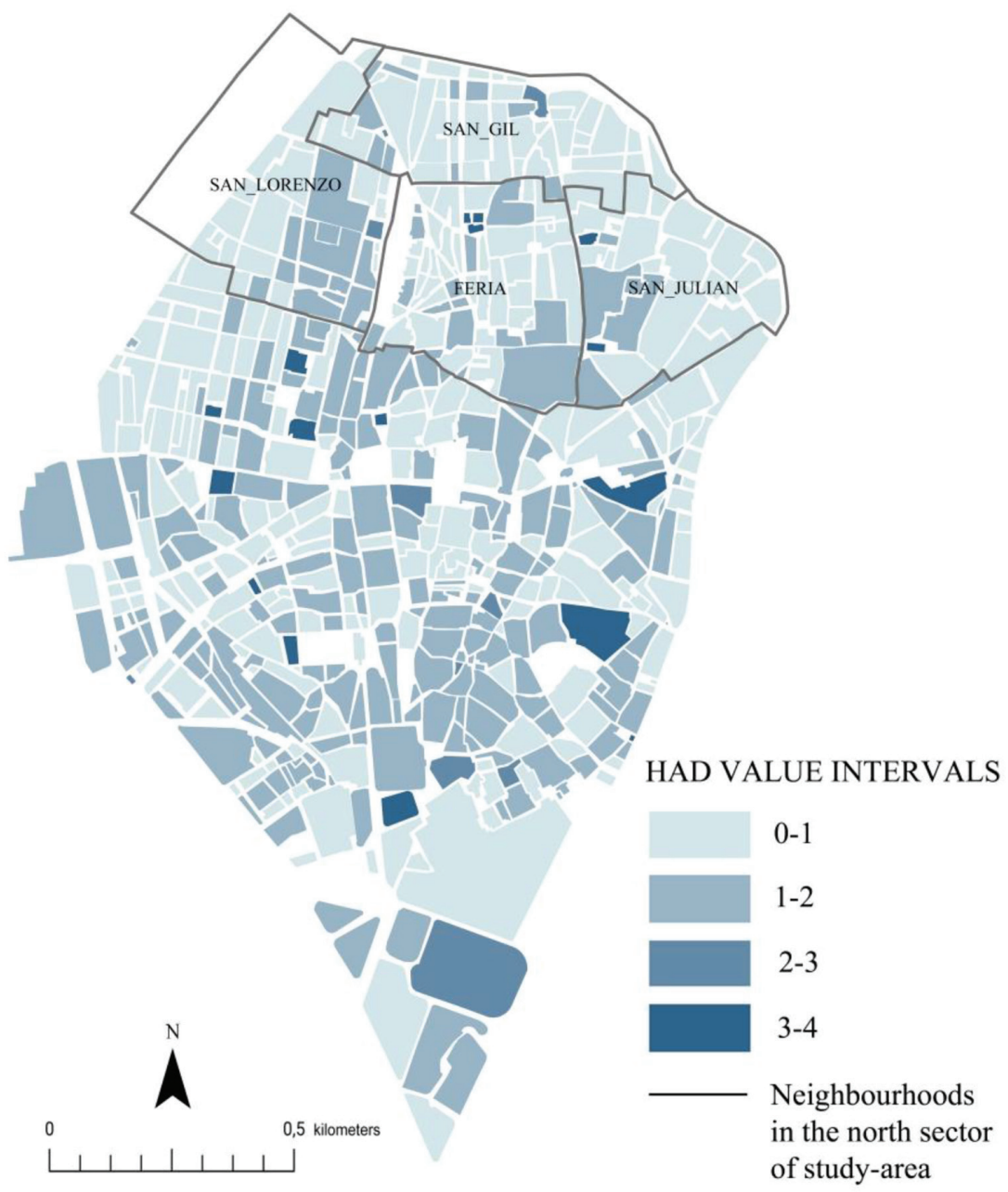

Figure 1: Heritage asset mapping. Spatial distribution of Heritage Asset Density (HAD) within the study-area.

between two partition walls that divide the properties. The back area of each plot remains empty to provide light and ventilation. Single family houses alternate evenly with multifamily houses. If the plot size is broad enough, some houses have a patio. It is common that the ground floor is dedicated to garage or commercial use.

\subsection{Method for block and buildings samples selection}

The methodology proposed involves proceeding in three stages. On Stage 1 a new parameter to quantify block-scale heritage assets was defined, 'Heritage Asset Density' (HAD). HAD value for each block in the study-area was calculated using the GIS tool ArcMap 10.2.1 (C) and the results were represented in a map (Fig. 1). The frequency distribution of HAD values, according to GIS results, was represented in the histogram shown in Figure 2. Thus, the study-area building stock (539 blocks) became segmented in four block-archetypes, 


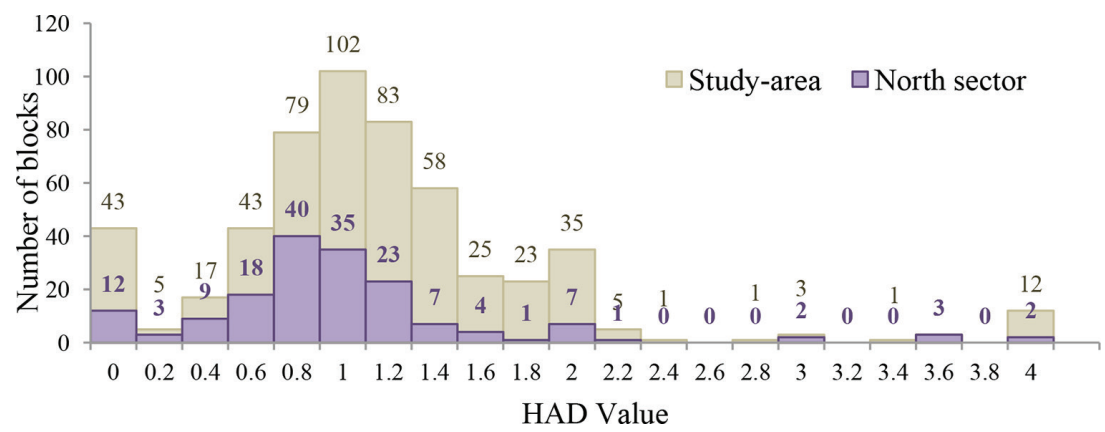

Figure 2: Histogram showing the comparison of frequency distribution of HAD value between study-area and north sector.

depending on the four intervals of HAD values established. The histogram provides the information about the average heritage heterogeneity, i.e. the most frequent combination of listed and not listed buildings. Blocks included in the most frequent interval are considered representative of the whole urban heritage asset and therefore candidates to become the simulated sample-block.

For each block, individual buildings were assigned an integer from 1 to 4 corresponding to their grading from $\mathrm{D}$ to A, respectively. HAD was then calculated as the sum of integers in the block divided by the number of buildings, thus representing the block's weighted average of heritage asset. HAD is independent of the land area occupied by the block or the constructed area it holds. Within the north sector (four neighbourhoods, 167 blocks, 24331 inhabitants) the most frequent HAD values are in the interval: $0.60-1$ and 85 blocks (51\%) meet that condition, as shown in Figure 2.

On Stage 2, the selected sample block was described. It is bounded by Feria (F), Relator(R), Antonio Susillo (AS) and Señor de la Sentencia (SS) streets (Fig. 3) and contains 23 buildings. Besides having the average HAD value, this block (hereafter called 'sample-block') presents other major advantages such as its regular shape and its almost exact solar orientation of its street façades. On the basis of information provided by the Cadastre [14], it was characterized according to three parameters: technical regulation period in which each building was
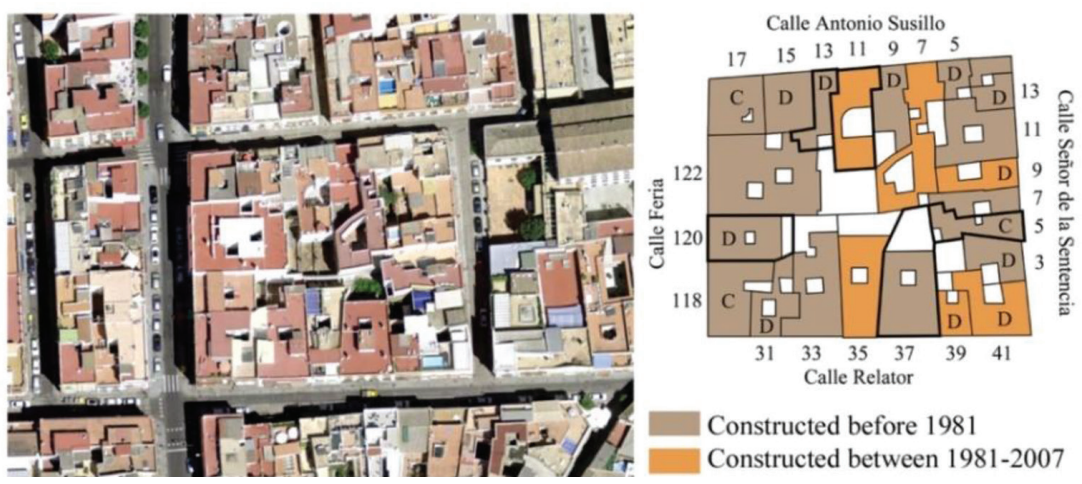

Figure 3: Sample block. Aerial photography (a); Plan with classification of buildings depending on technical regulation period and heritage listing grade (b). 
constructed or fully refurbished, listing grade and typology. Regarding regulation periods, two national-level legislative historic landmarks are relevant: 1981, year in which he first legislation on thermal isolation in buildings came into force (NTE-CT-79) [15] and 2007, were a more stringent mandatory energy technical code was implemented. Although this 2006 code was replaced by its 2013 version, stricter in terms of energy saving and energy efficiency, none of the 23 buildings was constructed or refurbished after 2006. Therefore, buildings within the sample-block were divided in two groups: one constructed or comprehensively refurbished before 1981, and a second group, between 1981 and 2007 (Fig. 3). Concerning typology, all the buildings are XX century storey-houses divided in two categories: single-family buildings (52\%) and multi-family buildings (48\%). Although all of them are of mandatory residential use, local regulations allow owners to use ground the floor as car-garage or as commercial premises.

On Stage 3, a group of five buildings was selected for thermal modeling. Their main characteristics are shown in Table 1. They all have flat roofs and none of them have basement. Heritage preservation rules for grades C and D are extracted from 'San Gil-Alameda' sub-district special plan. Among other elements, this plan protects the façades (original colours and materials, ornamental elements, forms and position of cornices, size and form of openings, mouldings of windows and doors, carpentry, locksmith's crafts) and roof typology.

\subsection{Simulation method and conditions}

CAD format building geometry was obtained from the Cadastre [14]. Heights and façade openings were approximated by on-spot verifications. The software Design Builder v.2.4.2.026 (C) was chosen for dynamic thermal simulation. Each building was divided in thermal zones according to floors and the shading and reflection effects of surrounding buildings were taken into account. The model does not consider thermal bridges and assumes high level air permeability of all openings. Surfaces of sample buildings in contact with adjacent ones were considered adiabatic, as both share similar thermal conditions. Parking and commercial spaces were removed from the simulation model as their thermal-conditioning and use patterns differ much from those of residential use. Surfaces adjacent to these spaces were considered adiabatic. In order to establish the operational conditions, the standard values contained in official documents were used [16-19]. Energy demand reference values of existing residential buildings in Seville were: $16.6 \mathrm{kWh} / \mathrm{m}^{2}$ for heating, $23.4 \mathrm{kWh} / \mathrm{m}^{2}$ for cooling and $12.3 \mathrm{kWh} / \mathrm{m}^{2}$ for domestic hot water [17]. The energy demand stipulated in current

Table 1: Main characteristics of the sample buildings.

\begin{tabular}{|c|c|c|c|c|c|c|}
\hline $\begin{array}{l}\text { Building } \\
\text { id. }\end{array}$ & $\begin{array}{l}\text { Construction } \\
\text { date }(* *)\end{array}$ & $\begin{array}{l}\text { Listing } \\
\text { grade }\end{array}$ & $\begin{array}{l}\text { Typology } \\
(*)\end{array}$ & $\begin{array}{l}\text { Ground floor } \\
\text { use }\end{array}$ & $\begin{array}{l}\text { Façade solar } \\
\text { orientation }\end{array}$ & $\begin{array}{l}\text { Usable sur- } \\
\text { face }\left(\mathrm{m}^{2}\right)\end{array}$ \\
\hline R37 & 2006 & - & MF-4 & Commercial & South & 690 \\
\hline F120 & 1960 & $\mathrm{D}$ & MF-4 & Residential & West & 539 \\
\hline AS11 & 2004 & - & $\mathrm{MF}-3$ & Residential & North & 321 \\
\hline AS13 & 1960 & $\mathrm{D}$ & SF-4 & Commercial & North & 195 \\
\hline SS5 & 1945 & $\mathrm{C}$ & MF-3 & Residential & East & 252 \\
\hline
\end{tabular}

(*) MF-X: multi-family X storey house / SF-X: Single-family X storey house $(* *)$ or full refurbishment date 
legislation is more restrictive: $15 \mathrm{kWh} / \mathrm{m}^{2}$ for heating and $20 \mathrm{kWh} / \mathrm{m}^{2}$ for cooling. Nonrenewable primary energy consumption maximum annual levels extracted from current legislation are depicted in Figure 4b. For the climatic zone of Seville, default values for thermal transmittance of constructive elements, depending on regulation period [16] are shown in the following Table 2.

\subsection{Data input}

Seville (Latitude: $37,42^{\circ} \mathrm{N}$, Longitude: $-5,90^{\circ} \mathrm{W}$ ) is located in a Mediterranean climate area, corresponding to Csa in the Köppen-Geiger climate classification [20] and included in zone B4 of the Spanish climatic zoning. Climate data came from ASHRAE, International Weather for Energy Calculations [21]. Fuel type was considered the same for all the buildings: natural gas from the public grid for domestic hot water and electricity supplied by public grid for household appliances and HVAC systems. All buildings were given the same values for activity characterization (occupancy schedule on workdays $0 \%$ from 8 to $16 \mathrm{~h}$ and $100 \%$ from 16 to $8 \mathrm{~h}$; on weekends and holidays $100 \%$ from 0 to $24 \mathrm{~h}$ conforming to typical Spain holiday schedule), natural ventilation ( $4 \mathrm{ac} / \mathrm{h}$ by window opening from 1 to $8 \mathrm{~h}$ summer local time), window protection (exterior blinds of medium reflectivity slats, working $100 \%$ on in summer from 11 to $21 \mathrm{~h}$ ) and lighting (minimum 150 lux, heat gain of $5 \mathrm{~W} / \mathrm{m}^{2}$, workdays from 6 to 8 $\mathrm{h}$ and from 16 to $24 \mathrm{~h}$; and weekends and holidays from 9 to $24 \mathrm{~h}$ ), miscellaneous heat gain of $5 \mathrm{~W} / \mathrm{m} 2$, domestic hot water $\left(60^{\circ} \mathrm{C}\right.$, consumption of $12.30 \mathrm{kWh} / \mathrm{m}^{2}$ [17] and environmental control systems (splits without mechanical ventilation, set point temperatures $21^{\circ} \mathrm{C}$ for heating and $25^{\circ} \mathrm{C}$ for cooling )

\section{THERMAL MODELLING}

3.1 Results and discussion of energy balance of current model.

According to simulation results shown in Table 3, AS13 and R37 complies with current energy demand limit values. Compactness and favourable solar orientation respectively might explain this good behaviour. On the other hand, thermal performance of AS11, whose

Table 2: Definition of thermal standards in current model for climatic zone B4.

\begin{tabular}{llllll}
\hline Parameter & Unit & Before 1981 & $1981-2007$ & $2007-2014$ & Post 2014 \\
\hline Façade U-value & $\mathrm{W} / \mathrm{m}^{2} \mathrm{~K}$ & 2.38 & 1.8 & 0.82 & 0.38 \\
Roof U-value & $\mathrm{W} / \mathrm{m}^{2} \mathrm{~K}$ & 2.17 & 1.4 & 0.45 & 0.33 \\
Ground floor* U-value & $\mathrm{W} / \mathrm{m}^{2} \mathrm{~K}$ & 1 & 1 & 0.82 & 0.38 \\
Slabs** U-value & $\mathrm{W} / \mathrm{m}^{2} \mathrm{~K}$ & 2.17 & 2.17 & 0.52 & 0.52 \\
Window U-value (***) & $\mathrm{W} / \mathrm{m}^{2} \mathrm{~K}$ & 5.7 & 5.24 & 4.2 & - \\
Solar Factor & & 0.82 & 0.82 & - & - \\
Infiltration & $\mathrm{m}^{3} / \mathrm{h} \mathrm{m}^{2}$ & 100 & 100 & 50 & 50 \\
\hline
\end{tabular}

* Up to $0,5 \mathrm{~m}$ deep

** Above non thermal-conditioned space

*** Frame and glass combined 
Table 3: Energy balance results of current model simulation.

\begin{tabular}{|c|c|c|c|c|c|c|c|c|}
\hline \multirow[b]{2}{*}{ Parameter } & \multirow[b]{2}{*}{ Units } & \multicolumn{6}{|c|}{ Sample building } & \multirow[b]{2}{*}{ Block } \\
\hline & & AS11 & AS13 & & SS5 & R37 & F120 & \\
\hline $\begin{array}{l}\text { Façade so- } \\
\text { lar orienta- } \\
\text { tion }\end{array}$ & & North & North & $\begin{array}{l}\text { North } \\
\text { (average) }\end{array}$ & East & South & West & \\
\hline TRP (1) & & $\begin{array}{l}1981- \\
2007\end{array}$ & $\begin{array}{l}\text { Before } \\
1981\end{array}$ & & $\begin{array}{l}\text { Before } \\
1981\end{array}$ & $\begin{array}{l}1981- \\
2007\end{array}$ & $\begin{array}{l}\text { Before } \\
1981\end{array}$ & \\
\hline Heating (2) & $\mathrm{kWh} / \mathrm{m}^{2}$ & 23.4 & 12 & 17.7 & 24.32 & 15.89 & 19.03 & 18.57 \\
\hline Cooling (2) & $\mathrm{kWh} / \mathrm{m}^{2}$ & 23.89 & 15.73 & 19.81 & 18.22 & 17.34 & 21.81 & 19.24 \\
\hline NREPC (3) & $\mathrm{kWh} / \mathrm{m}^{2}$ & 109.73 & 70.29 & 90.01 & 100.01 & 81.33 & 108.26 & 93.69 \\
\hline $\mathrm{CO}_{2}(4)$ & $\mathrm{kg} / \mathrm{m}^{2}$ & 70.05 & 68.06 & 69.055 & 60.97 & 57.39 & 77.50 & 65.99 \\
\hline
\end{tabular}

(1) Technical regulation period

(2) Annual energy demand values

(3) Non-renewable primary energy consumption annual values

(4) Emissions annual values

façade is equally solar-oriented than AS13, is much worse, even though it was constructed in the period in which insulation was compulsory. Its major proportion of façade in relation with its surface (shape-factor indicator) might explain this case. Altogether, heating and cooling demand values do not deviate significantly from the compulsory limit values for a building constructed today. In contrast, non-renewable primary energy consumption deviation (Fig. 4b) is mucho more considerable (on average 1.97 times the limit value). The largest deviation arises in heating demand, where only $40 \%$ of the buildings comply with the current threshold (Fig. 4a). This result is in accordance with those obtained by Sendra et al. [22, 23] and Girón et al. [24] for social housing in the same city; yet those values are much more higher than the values obtained in this study. Historic sample-buildings appear to use less energy than those analysed by the mentioned authors for the same city, built between 1955 and 1960 under Modern Movement design and constructive premises and with less
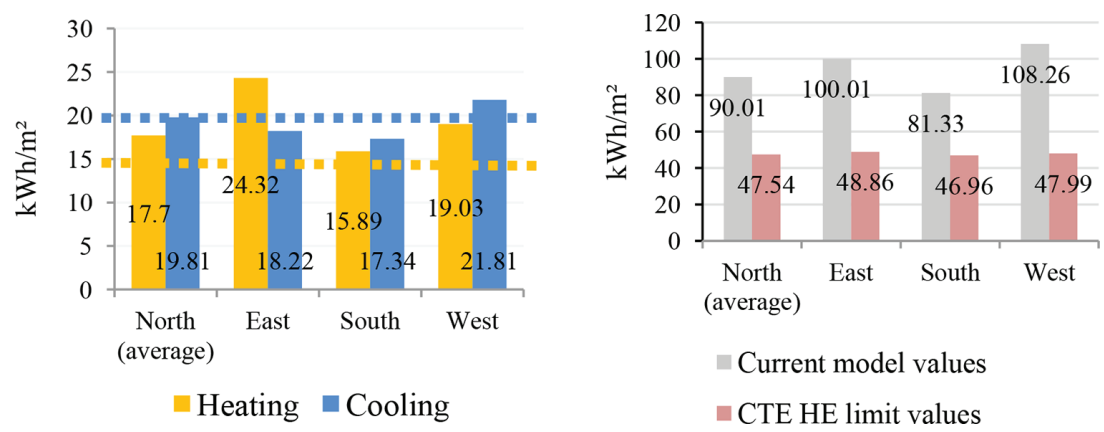

Figure 4: Energy balance results of current state by façade solar orientation. (a) Annual thermal energy demand; (b) Non-renewable primary energy consumption. 
favourable shape-factor. Technical regulation period does not seem to be relevant for thermal performance of buildings: the pair of samples which globally behave best (AS13 and R37) were constructed in different periods, while the worst accomplishment is carried out by a building constructed in the period 1981-2007(AS11), when thermal insulation of walls and roof was binding.

Summarizing, regarding combined thermal demand, $40 \%$ of the studied buildings demand less energy than the current limit value, and all deviate less than $30 \%$ of it. The buildings perform better for cooling (100\% either complain or deviate less than $30 \%$ ) than for heating (60\% either complain or deviate less than $30 \%$ ).

Up-scaling of results to block level was made by considering that the solar-orientation of the buildings' façades plays the most important role in thermal performance, as results seem to indicate. The results obtained as per solar orientation were next multiplied by the floor-area weighted of the complete block. Surfaces of corner buildings were equally divided to both solar-orientations. Comparison with the current limits is shown in Figure 5.

The current state sample-block complies with and even surpasses by $4 \%$ the current limit value in cooling demand. This means that the energy needed to maintain comfort conditions in summer is $4 \%$ lower than the energy needed for the same purpose by another block in Sevilla built after 2013 under the present legislation. Conversely, heating demand is not as favourable. The maintenance of the comfort conditions in winter demands $24 \%$ more energy than the reference present-day block aforementioned. For $100 \%$ of the sample-buildings energy supply comes from electricity and natural gas public grid and in Spain only $6 \%$ of the primary energy consumption (energy delivered to the consumer for being transformed in usable energy) derives from renewable sources [25]. Therefore, $\mathrm{CO}_{2}$ emissions are high. Current model block would obtain an $\mathrm{E}$ rating in $\mathrm{CO}_{2}$ emissions according to national system, compared to the compulsory energy rating A for any building constructed today.

\subsection{Potential for improvement of the sample block}

Once the results were analysed, three different sets of improvement measures (S0, S1, S2) were applied to the sample buildings depending on their individual balance. Five improvement measures were considered: Ia, Ib, Ic, Id and Ie. The three sets were: $\mathrm{S} 0=\mathrm{Ia}+\mathrm{Ib}, \mathrm{S} 1=$ $\mathrm{Ia}+\mathrm{Ib}+\mathrm{Ic}$ and $\mathrm{S} 2=\mathrm{Ia}+\mathrm{Ib}+\mathrm{Ic}+\mathrm{Id}+\mathrm{Ie} . \mathrm{S} 0$ and $\mathrm{S} 1$ are two different combinations of passive solutions, while $\mathrm{S} 2$ is a mix of solutions that include thermal transmittance improvements of the building envelope elements up to the threshold values.

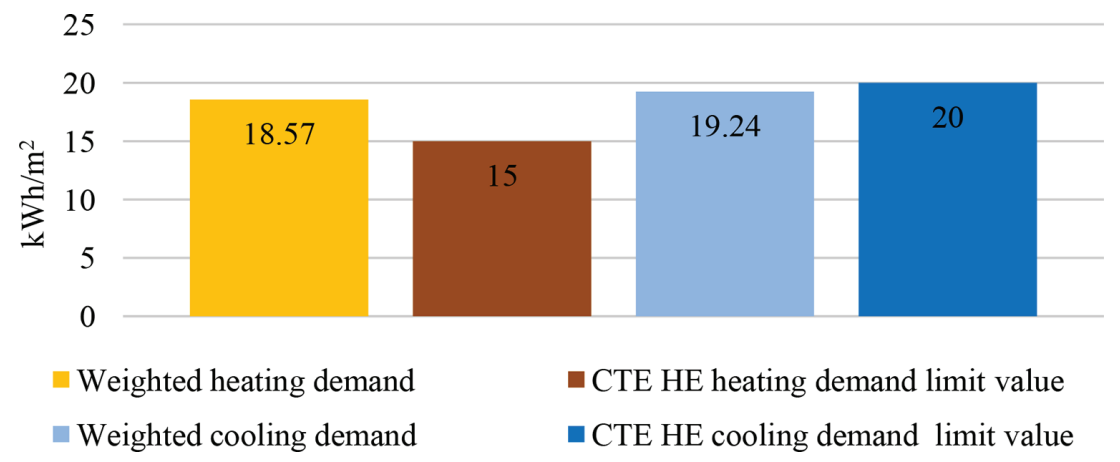

Figure 5: Weighted thermal demand for the sample-block compared with current thresholds. 
Improvement measures describes as follows: Ia: use of more efficient lamps and linear control systems implementation the decrease the lighting demand from $5 \mathrm{~W} / \mathrm{m}^{2}$ to $3.30 \mathrm{~W} /$ $\mathrm{m}^{2}$; Ib: implementation of household water saving devices to reduce water consumption from 28 litres to 21 litres per person and day, and a decrease in domestic hot water energy demand from the reference value of $12.30 \mathrm{kWh} / \mathrm{m}^{2}$ [17] to $9.23 \mathrm{kWh} / \mathrm{m}^{2}$ [26]; Ic: increasing natural night-time ventilation period in summer from 7 ( $1-8 \mathrm{~h}$ ) to 10 hours $(22 \mathrm{~h}-8 \mathrm{~h})$; Id: improving the thermal transmittance and airtightness of openings, up to the CTE thresholds. This solution includes the replacement of $100 \%$ of existing window frames, with no-thermal bridge break, for new aluminium frames with thermal break $\left(\mathrm{U}_{\text {frame }}=4.72 \mathrm{~W} / \mathrm{m}^{2} \mathrm{~K}\right)$ and replacement of existing $6 \mathrm{~mm}$ single-glass panes for new 6/16/6 double-glazed generic clear glass panes of thermal conductivity $\lambda=0.90 \mathrm{~W} / \mathrm{mK}$ and SF.077. In case the building demands excessive cooling energy, a solar control glass pane is placed on the outside $\left(\mathrm{U}_{\text {glass } 1}=2.65 \mathrm{~W} / \mathrm{m}^{2} \mathrm{~K}\right)$. The new thermal transmittance aggregate value (frame-glass) was $\mathrm{U}_{\text {opening } 1}=3 \mathrm{~W} / \mathrm{m}^{2} \mathrm{~K}$. In case the building demands excessive heating energy, gas argon substituted air into the internal chamber of the double glazing windows $\left(\mathrm{U}_{\text {glass } 2}=2.56 \mathrm{~W} / \mathrm{m}^{2} \mathrm{~K}\right)$, being the new thermal transmittance aggregate value (frame-glass) of $\mathrm{U}_{\text {opening } 2}=2.93 \mathrm{~W} / \mathrm{m}^{2} \mathrm{~K}(\mathrm{M} 4)$ ). Airtightness of openings is shortened from 100 to $\leq 50 \mathrm{~m}^{3} / \mathrm{h} \mathrm{m}^{2}$ for all cases. Finally, Ie: reinforcement of external insulation with mineral wool panels of thermal conductivity $\lambda=0.031 \mathrm{~W} / \mathrm{mK}$. Depending on the building performance, two different panel thicknesses were applied: 50 or $80 \mathrm{~mm}$.

Façades of $\mathrm{C}$ and $\mathrm{D}$ buildings cannot be covered according to the local preservation policy. In order to provide coherence to a hypothetical global refurbishment, the façades of non-protected buildings were considered as if they were protected as well. As such, only the interior courtyard walls were susceptible to be covered with insulation panels. For each building, depending on the proportion of the courtyard wall surface covered needed to attain thermal transmittance limit value ( $0 \%$, not larger than $50 \%$, between 50 and $70 \%$ or between 70 and $100 \%)$, four intensity of intervention levels (1,2, 3 and 4) were respectively established, regardless of the particular panel thickness $(50$ or $80 \mathrm{~mm})$ used.

\subsection{Results and discussion of sample-block retrofit}

$I a$ and $I b$ improvement measures were applied to all cases. Ic was applied to all the buildings except for AS13. Id was applied to all buildings excluding AS13 and R37, whose energy demand values don't exceed current limit values. So, three out of five buildings envelopes were enhanced with 6/16/6 double-glazed glass panes mounted on aluminium thermal-break frames in the $100 \%$ of the window openings. Ie improvement measure was applied to all buildings excluding AS13 and R37.

The application of the measures described above would ensure that all the sample-buildings would reduce their thermal energy demand up to current binding values, without worsening comfort conditions. Transformations in roofs or ground floors, schedules (except for night-ventilation Ic measure), operation schemes of occupancy and lighting, electric appliance gains and solar protection of windows systems were not needed.

According to the results shown in Table 4, the study concludes that $40 \%$ of the buildings required only passive measures (S0 and S1) and intervention of grade 1 (neither window frames and glass panes replacement nor external insulation panelling); $40 \%$ of the buildings required also non-passive measures (S2) and intervention of grades 2 and 3 (100\% window frames and glass panes replacement and external insulation panelling on less than $70 \%$ of the internal courtyard walls surface) and $20 \%$ of the buildings required also non-passive 
Table 4: Results of improvement capacity of the block analysis.

\begin{tabular}{llllll}
\hline \multirow{2}{*}{ Parameter } & \multicolumn{2}{l}{ Sample building } & \\
\cline { 2 - 6 } & AS11 & AS13 & SS5 & R37 & F120 \\
\hline Improvement set applied & S2 & S0 & S2 & S1 & S2 \\
PS $\left(^{*}\right)$ & $100 \%$ & $0 \%$ & $50-70 \%$ & $0 \%$ & $\leq 50 \%$ \\
Intensity of intervention & 4 & 1 & 3 & 1 & 2 \\
\hline
\end{tabular}

(*) Percentage of wall surface covered with external insulation

Table 5: Comparison on non-renewable primary energy consumption

\begin{tabular}{lllll}
\hline Building & Improvement set & Current threshold & Current state & Modified state \\
\hline AS11 & M4 & 48.12 & 121.31 & 77.29 \\
AS13 & M0 & 49.96 & 70.29 & 66.64 \\
R37 & M0 & 46.96 & 91.52 & 93.21 \\
SS5 & M3 & 48.86 & 100.01 & 69.4 \\
F120 & M2 & 47.99 & 108.26 & 91.21 \\
\hline
\end{tabular}

measures (S2) and intervention grade 4 (100\% window frames and glass panes replacement and external insulation panelling on $100 \%$ of the internal courtyard walls surface).

As the energy sources have not changed, all enhanced sample-buildings far exceed from the non-renewable primary energy consumption current threshold, as shown in Table 5.

\section{CONCLUSIONS}

Considering residential use, technical regulation periods and Heritage Asset Density (HAD) value as categorization parameters of the city case-study, the UBEM approach presented has obtained results from a generalizable block type which may serve to extrapolate the sort of general measures, and their costs, that would be needed to reduce energy usage at the scale of a historic neighbourhood.

Our results indicate that these measures are not far-fetched: the kind of interventions we have modeled on the buildings in order to decrease energy demand of the block down to current binding values, without worsening comfort conditions, and the intensity of such interventions, appear to be feasible. Heritage assets of the sample-buildings, which represent the most common kind of building in terms of heritage value, were not affected by the enhancements works proposed.

Therefore, the main conclusion is that the principal problem for the energy retrofit of Seville historic districts is not energy demand which, in global terms, does not exceed much the current limit values. The main problem is the excessive $\mathrm{CO}_{2}$ emissions: as the origin of the energy used to maintain the comfort conditions inside the buildings derives mainly from fossil fuels [25], the buildings are not particularly wasteful, but polluting.

While our work indicates that measures to reduce energy demand may be at hand $(40 \%$ would require only passive methods), reduction of carbon emissions will need of different strategies involving renewable energy sources. Distributed power generation together with 
mixed systems able to work with renewable and non-renewable sources are the key to longterm sustainability of historic districts.

\section{REFERENCES}

[1] von Rettberg, B. \& Rodriguez-Maribona, I., Assessment of European and national policies related to energy efficiency and heritage conservation. EFFESUS Project Deliverable D1.3, 2013.

[2] von Rettberg, B. \& Rodriguez-Maribona, I., European building and urban stock data collection. EFFESUS Project Deliverable D1.1, 2013.

[3] IDAE, Instituto para la Diversificación y Ahorro de Energía, 'Project Sech-Spahousec, Analysis of the Energetic Consumption of the Residential Sector in Spain', 2016.

[4] Ministerio de Fomento. Gobierno de España., 'Estrategia a largo plazo para la rehabilitación energética en el sector de la edificación en España, en desarrollo del Artículo 4 Directiva 2012/27/UE', 2014.

[5] Pracchi, V., Historic buildings and energy efficiency. The Historic Environment: Policy \& Practice, 5(2), pp. 210-225, 2014. https://doi.org/10.1179/1756750514z.00000000052

[6] Fouseki, K. \& Cassar, M., Energy efficiency in heritage buildings. future challenges and research needs. The Historic Environment: Policy \& Practice, 5(2), pp. 95-100, 2014. https://doi.org/10.1179/1756750514z.00000000058

[7] Intelligent Energy Europe Programme of the European Union, 'IEE Project TABULA. Typology approach for building stock energy assessment', 2012. [Online]. Available at: http://episcope.eu/iee-project/tabula/

[8] Intelligent Energy Europe Programme of the European Union, 'IEE Project EPISCOPE. Energy performance indicator tracking schemes for the continuous optimisation of refurbishment processes in European housing stocks', 2016. [Online]. Available at: http://episcope.eu/iee-project/episcope/

[9] Vieites, E., Vassileva, I. \& Arias, J.E., European initiatives towards improving the energy efficiency in existing and historic buildings. Energy Procedia, 75, pp. 1679-1685, 2015.

https://doi.org/10.1016/j.egypro.2015.07.418

[10] Reinhart, C.F. \& Cerezo Davila, C., Urban building energy modeling - a review of a nascent field. Building and Environment, 97, pp. 196-202, 2016.

https://doi.org/10.1016/j.buildenv.2015.12.001

[11] Monteiro, C.S., Pina, A., Cerezo, C., Reinhart, C. \& Ferrão, P., The use of multi-detail building archetypes in urban energy modelling. Energy Procedia, 111, pp. 817-825, 2017. https://doi.org/10.1016/j.egypro.2017.03.244

[12] Ayuntamiento de Sevilla, Portal de Datos Abiertos del Ayuntamiento de Sevilla | Catálogo de Datos. [Online]. Available at: http://datosabiertos.sevilla.org/data/

[13] Ayuntamiento de Sevilla, 'ide.SEVILLA'. [Online]. Available at: http://sig.urbanismosevilla.org/InicioIDE.aspx

[14] Ministerio de Hacienda y Función Pública, 'Sede Electrónica del Catastro'. [Online]. Available at: https://www.sedecatastro.gob.es/

[15] Real Decreto 2429/1979, de 6 de julio, por el que se aprueba la norma básica de la edificación NBE-CT-79, sobre condiciones térmicas en los edificios, pp. 24524-24550, 1979. 
[16] IDAE, Instituto para la diversificación y Ahorro de la Energía. 'Manual de fundamentos técnicos de certificación energética de edificios existentes CE3X (004,2)', 2015.

[17] IDAE, Instituto para la Diversificación y Ahorro de Energía. 'Condiciones de aceptación de procedimientos alternativos a LIDER y CALENER. Anexos', Efic. y Ahorr. energético, 2009.

[18] Ministerio de Industria, Energía y Turismo. 'Factores de emisión de CO2 y coeficientes de paso a energía primaria de diferentes fuentes de energía final consumidas en el sector de edificios en España', p. 16, 2016.

[19] Secretaria de Estado de Energía. 'Reglamento de las instalaciones térmicas en los edificios', 2013.

[20] Kottek, M., Grieser, J., Beck, C., Rudolf, B. \& Rubel, F., World map of the KöppenGeiger climate classification updated. Meteorologische Zeitschrift, 15(3), pp. 259-263, 2006. https://doi.org/10.1127/0941-2948/2006/0130

[21] 'International Weather for Energy Calculations | ashrae.org'. [Online]. Available at: https://www.ashrae.org/resources--publications/bookstore/ international-weather-for-energy-calculations

[22] Sendra, J.J., Proyecto Efficacia: optimización energética en la vivienda colectiva. Secretaria de Publicaciones de la Universidad de Sevilla, Sevilla, 2011.

[23] Sendra, J.J., Domínguez Amarillo, S., Bustamante Rojas, P. \& León Rodríguez, A.L., Energy intervention in the residential sector in the south of Spain: Current challenges. Informes de la Construcción, 65, pp. 457-474, 2013. https://doi.org/10.3989/ic.13.074

[24] Santamaría, J., Girón, S. \& Campano, M.A., Economic assessments of passive thermal rehabilitations of dwellings in Mediterranean climate. Energy and Buildings, 128, pp. 772-784, 2016. https://doi.org/10.1016/j.enbuild.2016.07.035

[25] Ministerio de Industria Energía y Turismo. 'La Energía en España 2015', 2016.

[26] Universidad de Sevilla, Universidad Pablo de Olavide, 'Aqua-Riba. Guía Para La Incorporación De La Gestión Sostenible Del Agua En Áreas Urbanas’, 2015. 